\title{
Modified Tripier flap in reconstruction of the lower eyelid ${ }^{*}$
}

\author{
Walter Luiz Granado Machado ${ }^{1}$ \\ Paula Cabral de Menezes Gurfinkel ${ }^{1}$ \\ Gustavo Vieira Gualberto ${ }^{1}$
}

\author{
Felipe Maurício Soeiro Sampaio ${ }^{1}$ \\ Marília Lopes Cavalcante Melo ${ }^{1}$ \\ Curt Mafra Treu ${ }^{1}$
}

Abstract: We describe the use of modified Tripier flap for reconstruction of a surgical defect in the lower eyelid region, after excision of nodular basal cell carcinoma.

Keywords: Ambulatory care facilities; Ambulatory surgical procedures; Carcinoma, basal cell; Eyelid diseases; Neoplasms, basal cell; Surgical procedures, operative

\section{INTRODUCTION}

Basal-cell carcinoma (BCC) is considered the most frequently diagnosed malignant cutaneous tumor in the dermatological practice. In spite of potential lateral invasion being greater than radial, metastasis cases have already been described in the literature. . $^{1,2,3}$

The treatment to be recommended depends on the hemodynamic state of the patients, histopathological subtypes, location and size of the tumor. Cryosurgery, photodynamic therapy and surgical exeresis are some of the existing tools.

\section{CASE REPORT}

Male patient, 51 years old, of mixed race, with a tumor measuring ${ }^{4}$ centimeters in diameter, well delimited, asymptomatic, located in the left infrapalpebral region, with two years of evolution (Figure 1). He presented himself in good general health without palpable adenomegalies.

Histological analysis of incisional biopsy sample revealed basaloid cell proliferation, with hyperchromatic nucleus and poorly defined cytoplasm forming nests in the dermis creating the aspect of peripheral palisade, typical of a solid nodular basalcell carcinoma.

Received on 30.9.2013.

Approved by the Advisory Board and accepted for publication on 30.10.2013.

* Work performed at Hospital Federal de Bonsucesso - Rio de Janeiro (RJ), Brazil. Financial Support: None

Conflict of Interests: None.

Hospital Federal de Bonsucesso - Rio de Janeiro (RJ), Brazil. 


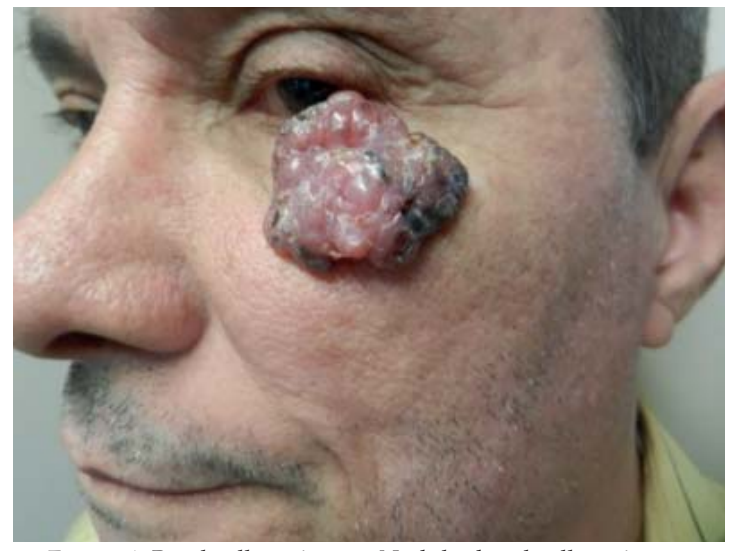

FIGURE 1: Basal-cell carcinoma. Nodular basal-cell carcinoma

During the intraoperative antisepsis and asepsis procedures were performed with degerming solution povidone-iodine (polyvinylpyrrolidone) and administration of $01 \mathrm{~g}$ of intravenous cefazolin. Local anesthesia was achieved with infiltration of a solution containing $15 \mathrm{ml}$ of $0.9 \%$ saline, $5 \mathrm{ml}$ of $2 \%$ lidocaine, $0.2 \mathrm{ml}$ of epinephrine and $2 \mathrm{ml}$ of $8.4 \%$ sodium bicarbonate.

Complete tumoral excision was planned with a safety margin of $5 \mathrm{~mm}$ and the removed material marked with nylon thread at 12 hours and submitted to histopathological study by intraoperatory freezing, obtaining analysis with neoplasm-free margins.

The surgical defect measured $5.0 \times 1.5$ centimeters, affecting all the lower left eyelid and upper left malar region. There was no involvement of mucosa and ipsilateral tarsal.

For the reconstruction of the defect it was recommended to perform a modified Tripier flap. The patient presented an excess of skin in the upper left palpebral region, enabling myocutaneous transposition of a local lobe to the surgical defect. The single pedicle, randomized and lateral, was drawn with a relatively wide base, avoiding involvement of the distal flap nutrition (Figure 2). Simple interrupted sutures were performed with mononylon 4.0 and 5.0 to position the flap without border tension and mononylon 6.0 for upper eyelid.

In the postoperative a local dressing was prescribed with ophthalmological eye ointment containing chloramphenicol, methionine, retinol acetate and aminoacids. Stitch removal occurred on the 7 th and 14th subsequent days. In the ninth month of ambulatorial follow-up patient remains with no relapses and with functional and esthetic palpebral outcome satisfactory (Figure 3).
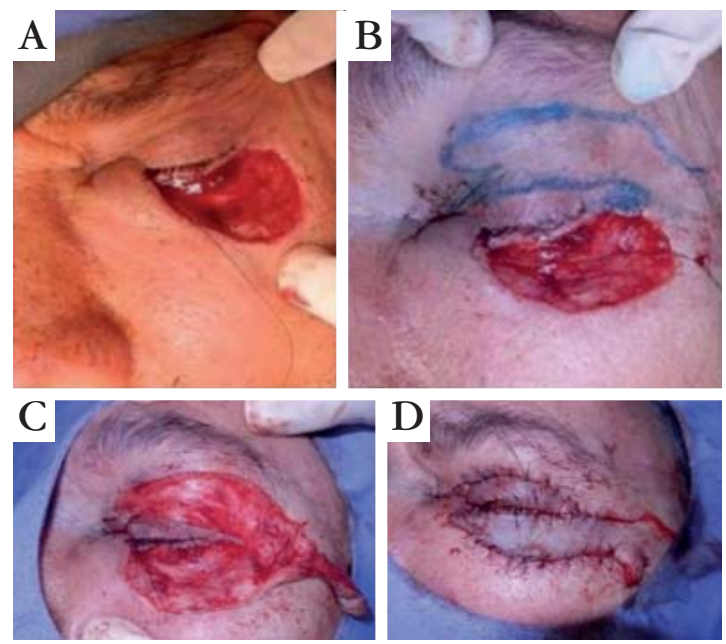

FIGURE 2: Intraoperative stages. A. Surgical defect after total exeresis of tumor. B. Demarcation of myocutaneous flap of upper eyelid. C. Observation of flap to be transposed and areas of primary and secondary defect. D. Flap positioned with lateral pedicule and direct closure of upper palpebral region
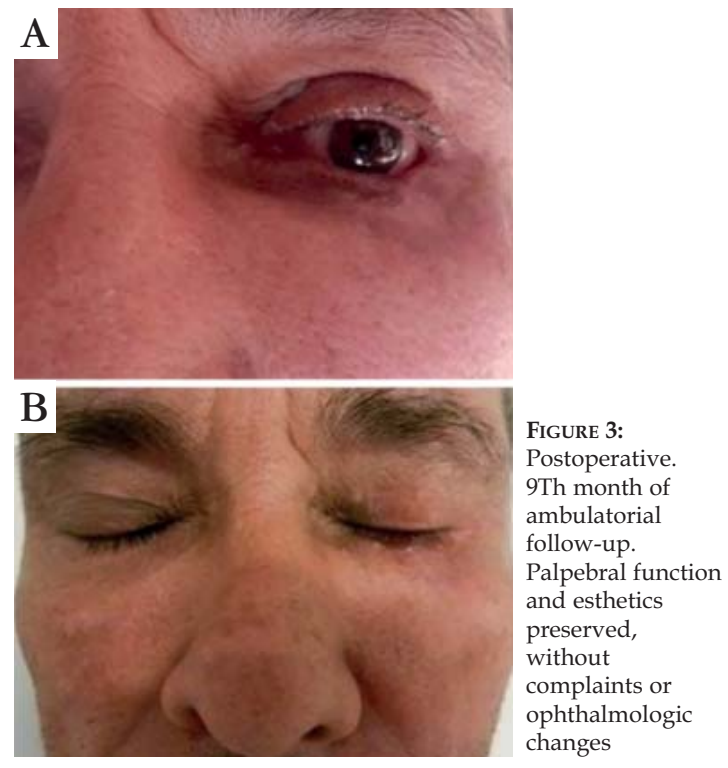

\section{DISCUSSION}

Tripier flap is considered a myocutaneous, bipedicular flap, originating from the upper eyelid and recommended for the reconstruction of defects located in the lower eyelid.4,5 It is a technique that requires a second surgical stage, usually after two 
weeks, for sectioning of lateral pedicles. Its modification consists in planning a single pedicle, lateral, randomized, which provides reconstruction, including the lateral portion of lower eyelid, without the need for a second surgical stage. ${ }^{4,5,6}$ The lobe to be transposed from upper eyelid to lower eyelid follows the proportion of 1:3 width $x$ length ratio, ensuring an adequate vascular support, avoiding necrosis, deformities and ectropion.

We must not mistake the modified Tripier flap for the Fricke flap. The latter is characterized as a purely cutaneous flap for transposition, monopediculated, from supraorbital region of frontal region to palpebral region. ${ }^{78}$

\section{REFERENCES}

1. Thiele OC, Mertens C, Bacon C, Flechtenmacher C, Zaoui K, Mischkowski RA. Facial basal cell carcinoma with successive metastases to the neck, thyroid gland and lung. J Craniomaxillofac Surg. 2014;42:489-91.

2. Wysong A, Aasi SZ, Tang JY. Update on metastatic basal cell carcinoma: a summary of published cases from 1981 through 2011. JAMA Dermatol. 2013;149:615-6.

3. Lara JLR, Kowalski LP, Miguel REV, Bottura L. Metastatic Basal Cell Carcinoma: a case report. An Bras Dermatol. 2001;76:429-35.

4. Bickle K, Bennett RG. Tripier flap for medial lower eyelid reconstruction. Dermatol Surg. 2008;34:1545-8.

5. Elliot D, Britto JA. Tripier's innervated myocutaneous flap 1889. Br J Plast Surg. 2004;57:543-9.

6. Nelson AA, Cohen JL. Modified tripier flap for lateral eyelid reconstructions. J Drugs Dermatol. 2011;10:199-201.

7. Herzog Neto G, Sebastiá R, Viana GA, Machado F. Eyelid reconstruction with Fricke's flap: report of two cases. Arq Bras Oftalmol. 2006;69:123-6.

8. Barba-Gómez J, Zuñiga-Mendoza 0, Iñiguez-Briseño I, Sánchez-Tadeo MT, BarbaGómez JF, Molina-Frechero N, et al. Total lower-eyelid reconstruction: modified Fricke's cheek flap. J Plast Reconstr Aesthet Surg. 2011;64:1430-5.
In cases of small surgical defects located in the palpebral region, vertical primary closure is preferred. Cicatrization by secondary intention, grafts and flaps are also options for the planning phase.,6

The whole set of good surgical planning, anatomical knowledge and adequate reconstruction technique indication make complications such as ectropion, epiphora, eyelid edema, hemorrhage and lagophthalmos infrequent.

This report aims at demonstrating an option of lower eyelid reconstruction, simple and versatile, as well as illustrating its steps regarding surgical planning.

\author{
MAILING ADDRESS: \\ Felipe Maurício Soeiro Sampaio \\ Av. Londres 616 \\ Bonsucesso \\ 21041-030 Rio de Janeiro, RJ. \\ E-mail:felipemauricio@uol.com.br
}

How to cite this article: Machado WLG, Sampaio FMS, Gurfinkel PCM, Melo MLC, Gualberto GV, Treu CM. Modified Tripier flap in reconstruction of the lower eyelid. An Bras Dermatol. 2015;90(1):108-10. 